http://journal.uinsgd.ac.id/index.php/biodjati

\title{
GROWTH AND FLAVONOID CONTENT OF Gynura procumbens (Lour) Merr. IN DIFFERENT SOIL WATER CONTENT
}

\author{
Evika Sandi Savitri*1, Farrikhatun Khusnia ${ }^{2}$
}

\section{Received : April 05, 2019 \\ Accepted : September 17, 2019 \\ DOI: 10.15575/biodjati.v4i2.4446}

Biology Department, Faculty of Science and Technology, Universitas Islam Maulana Malik Ibrahim Malang Jl. Gajayana 50, Malang 65145, Indonesia

e-mail:

*1evikasandi@bio.uin-malang.ac.id ningfarikha@gmail.com

*Corresponding author

\begin{abstract}
Gynura procumbens contains tannins, saponins, steroids, triterpenoids, essential oils and flavonoids which have bioactivity as a medicine for various diseases. One effort to obtain the quality of medicinal plants uses management of soil water content. The optimum of soil water content will support optimal growth of a plant. Whereas in conditions of low soil water content resulted in the induction of the production of secondary metabolites as a self-defense system. This study aimed to determine the effect of soil moisture content on the growth and total content of plant flavonoids G. procumbens. This study was carried out experimentally using a one-factor complete randomized design (CRD) consisting of 4 treatments with five replications. The treatment used is the difference in soil water content of $40 \%, 60 \%, 80 \%$ and $100 \%$ field capacity. The data obtained in the form of quantitative data will be analyzed by One Way ANOVA Test. Measurement of the content of total flavonoid compounds was carried out using UV-Vis spectrophotometer analysis. The results of the study indicate the influence of soil moisture level on the growth and total content of G. procumbens. Parameter growth of fresh weight, dry weight, and root G. procumbens showed an increase in $40 \%$ soil water content. The flavonoid content showed the highest total flavonoid content $18.884 \mathrm{mg} / \mathrm{g}$ in the $40 \%$ field capacity soil water content.
\end{abstract}

Keywords: flavonoid, G. procumbens, soil water content

\section{Citation}

Savitri, E. S. \& Khusnia, F. (2019). Growth and Flavonoid Content of Gynura procumbens (Lour) Merr. in Different Soil Water Content. Jurnal Biodjati, 4(2), 298-304

\section{INTRODUCTION}

Gynura procumbens (Lour) Merr. has various benefits, one of which is as a medicine. (Yam et al., 2008). Recently, herbal medicine using medicinal plants is starting to gain popularity as an alternative medicine because the price is cheaper than modern medicine and also has a potent efficacy (Chan et al., 2009).

G. procumbens (Lour) Merr. is a family of Asteraceae which is widely used by the community in Indonesia as traditional medicine, and they are mainly grown in Southeast Asian regions, such as Indonesia, Malaysia, and Thailand (Dash, 2016).

G. procumbens (Lour) Merr. commonly used as traditional medicine for inflammation, herpes, rash, rheumatism, kidney impairment, diabetes, cancer and hypertension (Dash, 2016). During G. procumbens (Lour) Merr cultivation. Water availability play a fundamental role in plant growth and development. The ideal water content for plant growth is 


\section{JURNAL BIDDJATI}

http://journal.uinsgd.ac.id/index.php/biodjati

in the optimum range of available soil water, ranging between $50 \%$ to $70 \%$ of available water. This differs based on the condition of field capacity (Drenovsky et al., 2004).

Water stress can occur due to a lack or an excess of water in the plant environment. Drought in plants occurs when there is a lack of water availability in the root area while at the same time there is excessive water demand by leaves due to the transpiration process (Rebey et al., 2012). The excessive water will harm plants and cause oxygen content low as soil pores to fill with water (Anggarwulan \& Mudyantini, 2005). Soil water content affects plant growth in Gynura divaricata. The optimal plant height, number of leaves, leaf area, as well as optimal growth was found in the plant in $60 \% \mathrm{KL}$ water content; optimal plant biomass found at $80 \% \mathrm{KL}$ water content; the optimal number of flower as well as the optimal water transport found at $40 \% \mathrm{KL}$ water content (Susanti \& Setiari, 2009).

The effect of $60 \%$ water content within field capacity in Sonchus arvensis can increase the flavonoid content, $2.11 \%$ higher than the control (Chang et al., 2002). The water availability of 40-60\% in Talinum paniculatum can increase tuber saponin levels up to $11.01 \%$ (Anggarwulan \& Mudyantini, 2005). The effect of $20 \%$ drought stress on the leaves could increase the saponin content of leaves $8.42570 \mathrm{mg} / \mathrm{g}$. While optimal biomass production showed in soil water content $40 \%$ $-80 \%$ of field capacity.

The purpose of this study was to determine the accumulation of secondary metabolites in this case, the total flavonoid content and plant growth under different conditions of water availability. So it is necessary to determine the content of bioactive compound of medicinal plants in different conditions of available soil water content.

\section{MATERIALS AND METHODS}

The experimental design using a one-factor Completely Randomized Design (CRD) consisting of four treatment levels, each treatment consisting of five replications as follows: $\mathrm{A} 0=100 \%$ field water capacity (control), A $1=80 \%$ field capacity, A2 $=60 \%$ field water capacity, A3 $=40 \%$ field water capacity (Drenovsky, 2004).

The tools and materials used in this study included measuring glass, moppets, UV-Vis spectrophotometers, vortices, spray bottles, $10 \mathrm{~mL}$ volumetric flasks, $50 \mathrm{~mL}$ volumetric flasks, ovens, analytical scales, mashers, 60 mesh sieves, beaker cups, maceration jars, aluminum foil, glass funnel, rotary evaporator, extract glass, spatula, cuvette, poly bag, thermometer, ruler, hygrometer, ethanol $96 \%$, standard quercetin solution, $\mathrm{AlCl}_{3} 10 \%$, $1 \mathrm{M}$ sodium acetate, filter paper, blue tip, and aquadest.

\section{Plant Media}

The plant media used for planting of seedlings was a composite soil from organic fertilizer, soil, and husk (1:2:1). Each polybag consist of one plant (Rahmah et al., 2014).

\section{Soil Water Content}

The several different levels of water content availability calculated using the Pressure Plate Method ( $\mathrm{pF}$ 2.54). The stages of methods are as follows: samples of dry soil were weighed and put into the sample ring according to the weight of the contents. The ring sample arranged on the apparatus pressure plate then let it saturated for \pm 24 hours. Then put in $\mathrm{pF}$ device and put pressure $1 / 3$ atm or $\mathrm{pF} 2.54$. Wait until the water drops stop (48 hours) then the soil is lifted, and the water content is determined. Determination of water content uses a gravimetric method. The mois- 


\section{JURNAL BIDDJATI}

http://journal.uinsgd.ac.id/index.php/biodjati

ture content of the field capacity from laboratory experiments (\% field capacity) served as the basis for giving water to the pot experiments at a greenhouse.

\section{Plant Cultivation}

Fertilization is carried out at the beginning of planting. This process is carried out by removing weeds that grow around the plant as well as controlling. pest and disease.

\section{Plant Sampling}

Plants sampling was taken around 28 days after treatment by picking leaves that have maturity physiology.

\section{Standard Quercetin Solutions}

A quercetin standard solution was made into several concentrations. A total of $0.5 \mathrm{~mL}$ of quercetin standard solution, 0.1 $\mathrm{mL}$ of aluminum (III) chloride $10 \%$ and 0.1 $\mathrm{mL}$ sodium acetate $1 \mathrm{M}$ were added into 2.8 $\mathrm{mL}$ of distilled water. Each solution concentration measured by its absorbance at a wavelength of $415 \mathrm{~nm}$ (Chang et al., 2002).

\section{Quercetin Standard Curves}

The standard curve of quercetin was made by correlating the concentration of a standard solution with absorbance obtained from measurements using a UV-Vis spectrophotometer.

\section{Determination of Total Flavonoid in Ex- tracts}

The $0.5 \mathrm{~mL}$ of the test sample together with $0.1 \mathrm{~mL}$ of aluminum (III) chloride $10 \%$ and, $0.1 \mathrm{~mL}$ of sodium acetate $1 \mathrm{M}$ were added into $2.8 \mathrm{~mL}$ of distilled water and shaked until homogeneous, then left for 30 minutes. The concentration was measured by its absorbance using a UV-Vis spectrophotometer at a wavelength of $415 \mathrm{~nm}$ (Chang et al., 2002).

\section{Data Analysis}

The data were analyzed using ANOVA (one-way analysis of variance), if there was a significant difference, then it was tested further with DMRT (Duncan Multiple Range Test) at the level of $5 \%$.

\section{RESULTS AND DISCUSSION}

\section{The Effect of Soil Water on Growth (Gynu- ra procumbens (Lour) Merr.)}

The results of the 5\% DMRT test on plant height showed that there were significant differences in each level of soil water content. The treatment of $80-100 \%$ field capacity was the optimal soil water moisture for development of plant height and leaf number. The treatment of $40-60 \%$ field capacity showed the higher leaf area, fresh weight, dry weight and root length (Table 1).

Table 1. The effect of soil water content on plant growth of Gynura procumbens (Lour) Merr. on 28 days after treatment

\begin{tabular}{ccccccc}
\hline Soil water content & $\begin{array}{c}\text { Plant height } \\
(\mathrm{cm})\end{array}$ & Leaf number & $\begin{array}{c}\text { Leaf area } \\
\left(\mathrm{cm}^{3}\right)\end{array}$ & $\begin{array}{c}\text { Fresh } \\
\text { weight } \\
(\text { gram })\end{array}$ & $\begin{array}{c}\text { Dry weight } \\
\text { (gram) }\end{array}$ & $\begin{array}{c}\text { Root length } \\
(\mathrm{cm})\end{array}$ \\
\hline $100 \%$ field capacity & $19.10 \mathrm{c}$ & $12.20 \mathrm{a}$ & $13.84 \mathrm{~b}$ & $6.72 \mathrm{a}$ & $0.66 \mathrm{a}$ & $15.40 \mathrm{a}$ \\
$80 \%$ field capacity & $17.30 \mathrm{~b}$ & $14.00 \mathrm{~b}$ & $17.43 \mathrm{c}$ & $8.54 \mathrm{ab}$ & $0.86 \mathrm{ab}$ & $16.20 \mathrm{a}$ \\
$60 \%$ field capacity & $17.10 \mathrm{~b}$ & $11.80 \mathrm{a}$ & $18.77 \mathrm{~d}$ & $10.12 \mathrm{~b}$ & $1.22 \mathrm{~b}$ & $18.50 \mathrm{~b}$ \\
$40 \%$ field capacity & $15.50 \mathrm{a}$ & $11.00 \mathrm{a}$ & $11.76 \mathrm{a}$ & $8.92 \mathrm{~b}$ & $1.14 \mathrm{~b}$ & $20.00 \mathrm{~b}$ \\
\hline
\end{tabular}

The number followed by the same letter shows that it is not significantly different from the DMRT test at the 5\% level. 


\section{JURNAL BIDDJATI}

http://journal.uinsgd.ac.id/index.php/biodjati

The decrease in soil water content will cause disrupted physiological and morphological activities and eventually cause cessation plant growth (Gopinath \& Pavadai,
2015). The level of soil water profoundly influences growth of the plant because the process of plant growth begins with the process of forming shoots (Figure 1).

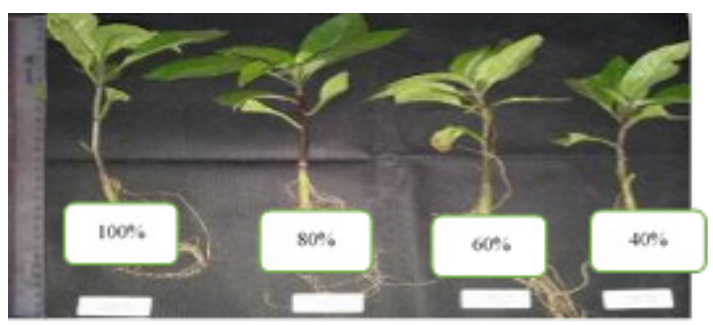

Figure 1. Plant Height G. procumbens at Different Soil Moisture Levels

The inhibition of plant growth can be due to several factors, including the availability of water. Availability of soil water is a significant factor in plant growth and development (Bergmark, 1987). The availability of water is crucial for plant growth, namely when the land is in a condition of field capacity. Field capacity is the maximum content of water in the soil after excess water leaves the soil due to gravity. The different soil water content also affects the number of leaves. The 5\% DMRT test results showed a significant difference between $100 \%$ field capacity with treatment of $80 \%$ field capacity.

The soil water content of $80 \%$ field capacity was the optimal treatment in development of leaf number. The lowest number of leaves was on the treatment of soil moisture content of $40 \%$ field capacity. The $80 \%$ field capacity can optimize the formation of leaves and result in the high of leaf number (Figure 2).

Several plants can optimize their growth when the water content in the soil reaches $40 \%$ field capacity. The treatment of $75 \%$ field capacity soil water content produced the highest number of leaves (Sullivan, 2002). Leaf area parameters showed a significant result in the level of soil moisture content of $100 \%$ field capacity. Soil water content of $60 \%$ field ca- pacity showed the optimal condition in forming leaf area, while the lowest leaf area was found in the treatment of $40 \%$ field capacity. When plants undergo $\mathrm{O}_{2}$ deficiency (anoxia) the process of growth and development in their leaf organs will decrease (Chen et al., 2002).

The treatment of various levels of soil water content also affects the plant biomass. The dry weight or biomass of the plants showed a significant difference between the treatment of $100 \%$ soil moisture content with the treatment of $60 \%$ field capacity and $40 \%$ field capacity (Xu et al., 2010).

The treatment of various levels of soil water content affects the root length. Plant root length showed a significant difference between $100 \%$ field capacity soil moisture treatment with $60 \%$ field capacity and $40 \%$ field capacity. The soil moisture of $40 \%$ field capacity showed the most extended root length. It means that the lower the availability of water in the soil, the longer the root formed (Figure 3).

Root lengthening in conditions of drought stress will hold the canopy growth rate by releasing growth hormone retardant which inhibits canopy growth, thereby increasing root growth. This mechanism is carried out by plants to prevent excessive water loss. 


\section{JURNAL BIDDJATI}

http://journal.uinsgd.ac.id/index.php/biodjati
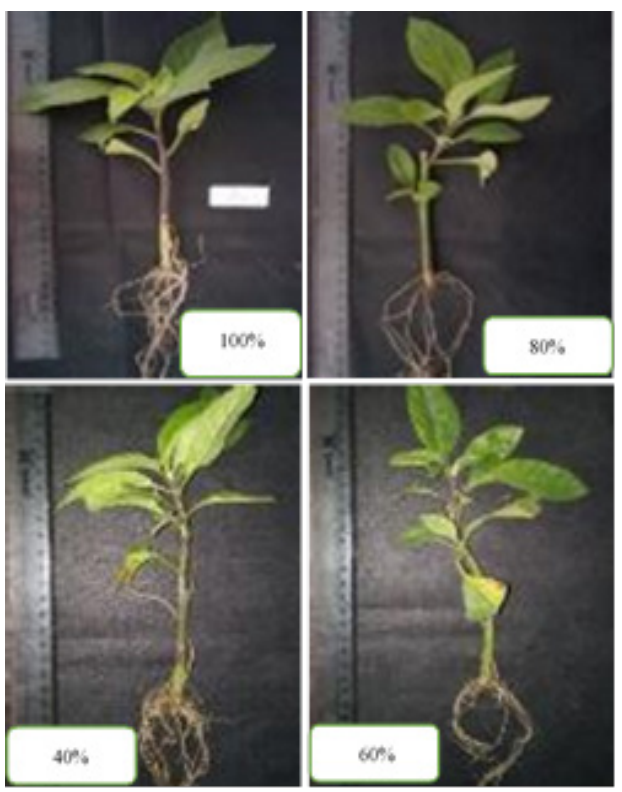

Figure 2. Number of leaves G. procumbens at Different Levels of Soil Moisture

The process of root extension can also affect the roaming of roots in the soil in order to absorb more water (Anggarwulan \& Mudyantini, 2005).

\section{The Effect of Soil Water Content on the To-} tal Flavonoid Content of Gynura procumbens (Lour) Merr.

The DMRT test results at the level of $5 \%$ showed that the total flavonoid content of leaves was significantly different between the

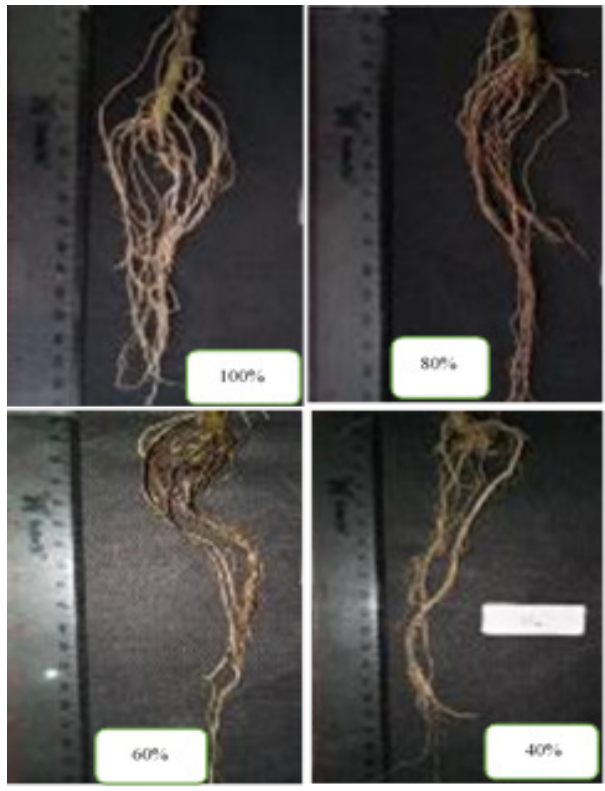

Figure 3. Plant roots of $G$. procumbens at different levels of soil water content $100 \%, 80 \%, 60 \%$ and $40 \%$ field capacity

control treatment of $100 \%$ field capacity and other treatments (Figure 4).

Based on figure 4 , the $100 \%$ field capacity produces the lowest total flavonoid content of $5.949 \mathrm{mg} / \mathrm{g}$ whereas at $40 \%$ field capacity showed the highest total flavonoid content of $18.884 \mathrm{mg} / \mathrm{g}$. Whereas under favorable conditions the production of secondary metabolites will be more dominant (Nakabayashi et al., 2014; Ghasemi et al., 2019).

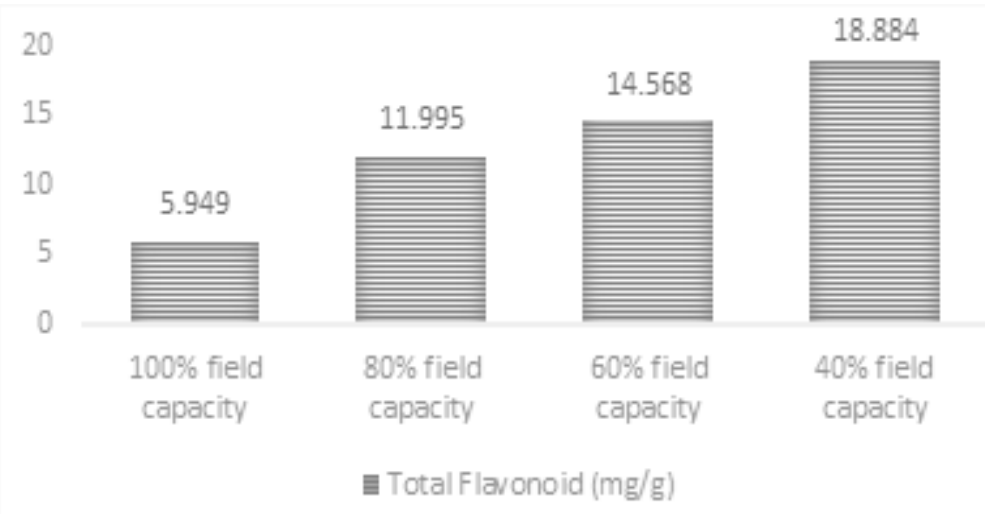

Figure 4. Total flavonoid content of leaves after 28 days of treatment $(\mathrm{mg} / \mathrm{g})$ 


\section{JURNAL BIDDJATI}

http://journal.uinsgd.ac.id/index.php/biodjati

The results of previous study showed that the treatment of $60 \%$ water deficit stress on tempuyung (Sonchus arvensis L.) can increase the highest flavonoid content, which is 2.11\% higher than the control (Chang et al., 2002; Yang et al., 2007). The results of this study showed that the lower the soil moisture content, the higher the content of flavonoids produced. Phenylpropanoid metabolism is affected in the early period of drought stress. During drought stress, phenylpropanoid metabolism is very active with high activation phenylalanine ammonia lyase (PAL) which increased phenol and flavonoid content (Ghasemi et al., 2019). Flavonoid compounds function as antioxidants of antidotes to various diseases. It is suggested that the research regarding the effect of soil moisture content on the content of other secondary metabolites which have bioactivity as drugs should be conducted.

Based on the results of the research it can be concluded that the level of soil moisture content affects the growth and content of the total flavonoids in G. procumbens plants. The level of soil moisture content of $40 \%$ field capacity produces the highest total flavonoid content of $18.884 \mathrm{mg} / \mathrm{g}$. The optimal of growth was in moisture content of 100-80\% field capacity, while the optimal root length development was found at soil moisture content $40 \%$ field capacity. The level of soil moisture of $40 \%$ field capacity can be reference to produce the secondary metabolites.

\section{ACKNOWLEDGMENTS}

I would like to acknowledge Genetic and Molecular Biology Laboratory, Biology Department UIN Maulana Malik Ibrahim Malang, Phytochemistry Laboratory, Materia Medica Malang.

\section{REFERENCES}

Anggarwulan, E. \& Mudyantini, W. (2005). Pengaruh Ketersediaan Air terhadap Pertumbuhan dan Kandungan Bahan Aktif Saponin Tanaman Ginseng Jawa ( Talinum paniculatum Gaertn.). Biofarmasi, 3(2), 47-51.

Bergmark, C. S. K. C. L. (1987). Growth and Development of the Florunner Peanut Cultivar as Influenced by Population, Planting Date and Water Availability. Peanut Science, 14, 11-16.

Chan, L. K., Lim, S. Y. \& Pan, L. P. (2009). Micropropagation of Gynura procumbens (Lour.) Merr. an important medicinal plant. Journal of Medicinal Plants Research, 3(3), 105-111.

Chang,C., Yang, M., Wen,H.\&Chern,J.(2002). Estimation of Total Flavonoid Content in Propolis by Two Complementary Colorimetric Methods. Journal of Food and Drud Analysisi, 10(3), 178-182.

Dash, P. R. (2016). A Comprehensive Review on Gynura procumbens Leaves. IJP, 3(4), 167-174.

Drenovsky, R. E., Vo, D., Graham, K. J., \& Scow, K. M. (2004). Soil Water Content and Organic Carbon Availability Are Major Determinants of Soil Microbial Community Composition. Microbial Ecology, 48(3), 424-430.

Ghasemi, S., Kumleh, H. H. \& Kordrostami, M. (2019). Changes in the Expression of Some Genes Involved in the Biosynthesis of Secondary Metabolites in Cuminum cyminum L . Under UV Stress. Protoplasma, 256, 279-290.

Gopinath, P. \& Pavadai, P. (2015). Morphology and Yield Parameters and Biochemical Analysis of Soybean (Glycine max (L.) Mrr.) Using Gamma Rays, EMS and DES Treatment. International Let- 


\section{JURNAL BIDDJATI}

http://journal.uinsgd.ac.id/index.php/biodjati

ters of Natural Sciences, 35, 50-58.

Hendriyani, I. S. \& Setiari, N. (2009). Kandungan Klorofil dan Pertumbuhan Kacang Panjang (Vigna sinensis) pada Tingkat Penyediaan Air yang Berbeda. J.Sains \& Mat., 17(3), 145-150.

Nakabayashi, R., Mori, T. \& Saito, K. (2014). Alternation of Flavonoid Accumulation Under Drought Stress in Arabidopsis thaliana. Plant Signaling and Behavior, 9(8), e29518-1-e29518-3.

Rahmah, Munifatul Izzati, S. P. (2014). Pengaruh Pupuk Organik Cair Berbahan Dasar Limbah Sawi Putih (Brassica chinensis L.) Terhadap Pertumbuhan Tanaman Jagung Manis. Buletin Anatomi dan Fisiologi, 22(1), 65-71.

Rebey, I. B., Jabri-karoui, I., Hamrouni-sellami, I. \& Bourgou, S. (2012). Effect of Drought on the Biochemical Composition and Antioxidant Activities of cumin (Cuminum cyminum L .) seeds Effect of Drought on the Biochemical Composition and Antioxidant Activities of Cumin (Cuminum cyminum L.) seeds. Industrial Crops \& Products, 36(1), 238-245.
Sullivan, B. P. (2002). Drought Resistant Oil. NCAT Agriculture Specialist.

Xu, Z., Zhou, G. \& Shimizu, H. (2010). Plant Responses to Drought and Rewatering. Plant Signaling and Behavior, 5(6), 649-654.

Yam, M. F., Sadikun, A., Asmawi, M. Z. \& Rosidah. (2008). Antioxidant Potential of Gynura procumbens. Pharmaceutical Biology, 46(9), 616-625.

Yang, Y., He, F., Yu, L., Chen, X., Lei, J., \& Ji, J. (2007). Influence of Drought on Oxidative Stress and Flavonoid Production in Cell Suspension Culture of Glycyrrhiza inflata Batal. Zeitschrift Für Naturforschung C, 62(5-6), 410-416. 